\title{
The Enterprise Risk Profile Model and Its Implementation in Reorganised Companies
}

\author{
Cristina STROIE \\ Bucharest University of Economic Studies, Romania \\ cristina.stroie@cig.ase.ro \\ Adriana DUȚESCU \\ Bucharest University of Economic Studies, Romania \\ adriana.dutescu@ase.ro
}

\begin{abstract}
Globalization, as a response to the accelerated developments in recent decades, has shifted the world economy to a direction in which the adaptation to uncertainty conditions has been one of the most important manifestations of rational behavior. Human activity has always been subject to risks and uncertainty, and environmental pressure naturally generates selection and adaptation. The risk profile analysis in insolvency proceedings, as an indicator of managerial and financial health, represents a challenge to complement the gaps in the literature, given the limited studies in the field, compared to the bibliography in the field of risk management, for the companies in the economic circuit. This topic is of major importance for all business environments, having in view the disasters generated by economic crises on companies. In terms of judicial reorganization and insolvency proceedings, the situation in Romania proves to be different from the practices in the countries with tradition in this field and we are referring here to the USA, Germany and France. Comparative studies have indicated dysfunctions in the reorganization procedures in Romania, related to the lack of a coercive system to remove the insolvency debtors from the economic circuit, and the lack of models for analyzing the reorganization capacity of companies in insolvency proceedings. Regarding a possible reorganization of a company, creditors do not have approved analysis models in order to vote on reorganization plans and most of the time, at least as far as public creditors are concerned, their vote is negative and unfounded. The purpose of this research is to generate a model of internal risk analysis specific to the companies undergoing insolvency proceedings and of external risks related to the activity sector, a model able to predict the possibility of reorganizing a company undergoing insolvency proceedings. The main tool used is the interview, conducted on a sample of insolvency experts in Romania, with an average experience of approx. 10-20 years in insolvency and reorganization activities. Based on the analysis of the obtained results, we will refine and restructure a model, and then we will test it on a sample of companies undergoing insolvency proceedings.
\end{abstract}

Keywords: insolvency proceedings, judicial reorganization, risk profile analysis, business sustainability, reorganization decision.

\section{Introduction}

In recent years, the development of international markets has made companies adapt to new business co-ordinates. The sustainability and development of companies require increased adaptability and the establishment of an appropriate, organized and regulated environment for business organization in the context of globalization. 
The need to adapt to the uncertainty of the business environment has triggered the modernization and development of the conceptual framework associated with notions such as uncertainty and risk, risk management, risk assessment and, consequently, the identification of good practice models to safeguard companies.

International collaboration has also led to reforms in insolvency proceedings, in order to provide honest debtors with a second chance to reorganize. Therefore, business turnaround (i.e. the reorganization of an insolvent company) attempted to minimize company losses, which, according to the statistics provided by the EU in 2016, over 200,000 businesses were affected annually by insolvency, and the social impact indicated a loss of more than 1.7 million jobs (European Commission, 2016).

The US insolvency law has been encouraging a second chance only since 1867, although a minimum debt discharge was also included in the first form of the Bankruptcy Act (1800). The Bankruptcy Code was adopted in the US in 1979. The first empirical reorganization attempt was provided in the Austrian legislation of 1914 (Giné, X. \& Love, I. 2006).

In the following years, the bankruptcy legislation was adopted in Italy (1979), France (1985), Great Britain (1986), New Zealand (19890, Australia and Canada (1992), Germany (1994 and 1999), Sweden (1996), Japan and Mexico (2000). The post-communist countries, including China and Russia, introduced and respectively improved bankruptcy laws only after 1990. In Romania, the first law on reorganization was adopted in 1995.

In this research, we have approached conceptually and practically the main features of the risk profile of companies undergoing reorganization as part of the insolvency proceedings. In this regard, we wanted to present the opinion of professionals, i.e. insolvency practitioners with an average experience of over 10 years, who carry out their activities in Romania.

It is well known that there is no recipe for success on which companies should reorganize. The process of reorganizing a company is complex; it involves time and effort, based on a whole series of processes, factors, logistical constraints and professional reasoning. Due to the complexity of this approach, very different effects can occur, even for companies that are similar in terms of activity, size etc. The debtor undergoing insolvency proceedings, such as a company in the economic cycle, faces a number of risks (events/ contexts/ situations, etc.) that can reduce the success of the reorganization plan.

This study contributes in several ways to this field that has been researched insufficiently until now, i.e. the judicial reorganization procedure of insolvent companies (Ramkrishnan V. T. et al., 2016; Laitinen, 2010).

First, Romania has improved its insolvency proceedings by encouraging the restructuration based on the US and the EU specific legislation, and therefore the results of this specific study on the reorganization procedures in Romania are of general relevance.

Second, this study presents a risk profile for these companies in terms of the effectiveness of insolvency proceedings, namely the need to provide a framework for supporting viable companies and eliminating those without a recovery potential. Although the insolvency law encourages the reorganization of companies, the success rate of these procedures is low, according to the statistical data provided by various participants in the Romanian procedure (ANAF - National Agency for Fiscal Administration, UNPIR - National 
Union of Insolvency Practitioners in Romania, etc.). Thus, although 95\% of the insolvency files have a recovery intention, only a small percentage, i.e. up to $1-3 \%$, successfully completes the reorganization process. Therefore, the greatest risk is to encourage nonviable companies to continue their activities, generating high costs in the economy and chain insolvency, i.e. the so-called "domino effect".

The main purpose of this paper is to generate a risk analysis model, specific to insolvency proceedings, able to provide the participants in the procedure, i.e. insolvency practitioners, financial auditors, taxpayers, creditors, with a clearer picture regarding the chances of the judicial reorganization of the companies involved in this procedure.

In order to identify the risks with a major impact on the judicial reorganization process, we used the qualitative research methodology, by analyzing the literature, along with the observation method and the development of a structured interview addressed to the insolvency practitioners who carry out their activities in Romania.

We analyzed the following aspects, in terms of the respondents' perception:

1. What are the most important risks that affect an insolvent company?

2. What business analysis methods do you use, when assessing the companies' capacity to reorganize the business, under the reorganization plan?

3 . What are the main aspects taken into consideration when analyzing the possibility of reorganizing a company through a reorganization plan versus the bankruptcy version?

The article continues our previous research focused on identifying the companies' risk profile, as a factor of their financial and managerial health, in terms of insolvency proceedings (Dutescu \& Stroie, 2018). In the previous research, we used qualitative research methodology based on case studies, comparative studies whereby we identified the correlations between different insolvency systems and the applicable fiscal policy, in order to analyze the causes limiting the reorganization of companies in judicial proceedings (Stroie \& Mirea, 2018; Dutescu \& Stroie, 2018).

In insolvency proceedings, there are several procedural aspects influencing the success of a possible reorganization plan, which is equivalent to the reinsertion of the company into the economic circuit. There are also some minimal requirements of the reorganization plan, designed to provide an acceptable information level that can entail the establishment of a grounded opinion on the reorganization of the respective company.

\section{Literature review}

\section{The concept of risk}

The first evidence of the notion of "risk" was identified in the Hammurabi Code (Babylon, written around $1760 \mathrm{BC}$ ); however, until the $17^{\text {th }}$ century, the risk was not scientifically analyzed (Wood, Oliver G., 1964).

In 1713, Jacob Bernoulli formulated the Law of Large Numbers, using the notions of probability, statistical significance and the theories related to sampling procedures and methods (Daltu, 2006).

Among the first attempts to define the notion of "risk", in terms of loss chances, belonged to John Haynes, in his paper "Risk as an Economic Factor (Haynes, 1895). According to him, "risk" signifies economically "the chance of damage or loss" and his statements about risks led us to the idea that at that time, i.e. in 1895, the definition was 
generally accepted. Later, other economists (J. B. Clark, 1899; Allan H. Willett, 1901) approached the risk as the reward of the entrepreneur for his assumptions. In 1921, in his reference paper "Risk, Uncertainty and Profit", F. H. Knight differentiated the notion of risk, which he considered measurable, and the concept of uncertainty, for which he did not identify any assessment possibility.

At the same time, there have been substantial contributions to the evolution of the literature in the field of risk analysis and risk management (H. M. Markowitz, 1952, R. Gallagher, 1956). Since the middle of the last century, studies in the field have incorporated complex managerial strategies based on some statistical mathematical models that would accurately estimate the evolution of some reference indicators in the activity of risk managers (J. Neumann and O. Morgenstern, 1944 H. Marcovitz, 1952, F. Black and M. Scholes, 1970).

\section{Business turnaround and business reorganization}

The effects of major global economic and financial crises have raised the interest of practitioners and researchers alike in deepening the mechanism of saving companies from decline (Chandler, AD 1962, Cameron K. et al., 1983, Coldwell C. et al., 2004, Ghazzawi, I. and Cook, T. (2015). However, the subject is still far from being elucidated. In this regard, business rescue has been approached and defined as a significant improvement method in the financial and operational situation, due to strategic actions aimed at identifying new resources (T. Lohrke, F. et al., 2004, Trahms, CA et al., 2013, Ghazzawi, I., 2018).

It is noteworthy that reorganization was generally analyzed by reference to the greatest dangers, represented by business bankruptcy. Over the years, many analysis models have been identified, signaling the bankruptcy risk, such as Altman's Score (1968), which is the starting point for numerous studies using correlated and weighted financial indicators, for the most accurate estimation of bankruptcy risks.

The sector of insolvency proceedings was mainly addressed in terms of bankruptcy risks, most studies and research being aimed at improving the prediction by different financial variables (such as profitability, liquidity, enterprise size, leverage), and/ or nonfinancial ones (industry, company duration, management characteristics, audit reports etc.) (Altman, 1968; Liou \& Smith, 2007; du Jardin, 2015; Lukason O. et al., 2016; Vissak \& Lukason, 2017; Gabbianelli L., 2018; etc.).

The procedures for the judicial reorganization of insolvent companies have been addressed insufficiently in literature, and most authors refer to this issue (Routhledge \& Gadenne, 2004; Laitinen, 2008, Éva Pálinkó \& Tamás Tóth, 2017).

This problem (i.e. insufficient studies on judicial reorganization) is caused by the shortage of financial and non-financial information databases from insolvent companies. The reorganization procedure of insolvent companies usually lasts - on average - between one and four years (Smith \& Graves, 2005). Later, if the company is successfully reorganized, it is reinserted into the economic mainstream (the main stages of the reorganization process are presented according to Figure 1).

\section{Methodology}


The main purpose of the current research is to collect and analyze professionals opinion on the main possible characteristics of a risk profile of companies under reorganization procedure. Our opinion is that this topic, belonging to behavioral sciences, is better emphasized by a qualitative research methodology, in order to provide a thorough understanding of this multi-dimensional subject.

The importance and role of qualitative studies in assessing the target population's perception on different events and scenarios have been analyzed by different previous studies (Bardi, 2007, and others). In this respect researchers are directly involved in the process of designing and conducting the research methodology pattern, their knowledge, experience and understanding of the cultural, economic and social environment under the scrutiny being important features of this endeavor (Birkinshaw et al., 2011). "Qualitative research is inevitably influenced by the researchers' identity, their own opinions, interpretations, and conceptual alignments, because they are the most implicated in this process and) they have to identify and to decide which company can survive and those which ultimately fail. (Pugna et Dutescu, 2019)".

We based our research on grounded theory (Glaster \& Strauss, 1967), suitable to the settled scope: behavioral exploration of perceptions on what a profile risk should be, for companies under reorganization procedure. Based on this conceptual framework we aimed to identify the main characteristics and factors that are crucial for reorganization procedures of insolvent companies (Goulding 2002).

This qualitative analysis is part of an integrated, more complex project, blending qualitative research with quantitative instruments. The current paper is focusing only on the qualitative research angle, future research aiming to integrate both perspectives (qualitative and quantitative assessment of the subject).

The research was based on an interview, addressing three open questions to professional with experience in company reorganization and insolvency procedures, in order to assess their perception on the following topics.

The research questions were the following:

a) Which are the main risks that generally affect companies under insolvency procedure?

b) Which are the main drivers that influence professionals' analysis and opinion on companies reorganization's patterns and frameworks?

c) What are the main risks that have affected companies under reorganization procedure?

The interview structure was designed to capture respondents' awareness and experience on different areas of company's reorganization and insolvency procedures and to find a pattern on major techniques and instruments used by professionals in order to document their opinion.

The interview was based upon four questions, addressed to the insolvency practitioners:

1. Which are, based on your professional experience, the main risks that affect an insolvent company?

2. What business analysis methods do you use, when assessing companies capacity to reorganize the business, under the reorganization plan? 
3. What are the main issues taken into consideration when you analyze a company's capacity to apply a reorganization plan or decide bankruptcy?

4. Please make a ranking of the most important risks, events, contexts, etc. which limit a company's ability to reorganize itself on a plan basis.

The interview was administrated via email and isondaje.ro platform, in the interval between December 2018 and January 2019 and was based upon the five questions highlighted above.

The first open topic aimed to assess professionals' opinion on major risks that affected businesses under the insolvency procedure and corresponds to the first research question.

The second topic was designed to match the second research question and is aimed to collect respondents opinions on main methods and instrument used to ground their analysis and opinion.

The third and the fourth topic is investigating respondents opinion of the main risks that company under reorganization proceedings is facing and is matching the last research question.

The target population consists of insolvency professionals, with minimum ten years of business experience in a variety of industries. They were selected based on membership to the Romanian professional Body: National Union of Insolvency Practitioners of Romania (UNPIR) and their thorough experience on the investigated topic. Based on this population of almost 2.800 actives practitioners, a number of 70 professionals (most of them Presidents of the UNPIR branches, and also practitioners with a recognized activity in this field) was selected, the sample being representative both in terms of experience, background and geographical spread (Whitman and Woszcynski, 2003). The total number of collected responses was 38 .

This connection between researchers and participants involved was not a direct one, even though one of the researchers is a professional in the UNPIR.

For this investigation, we have adopted appropriate ethical standards. The anonymity of the respondents was ensured, and all ethical research standards were followed.

\section{Results and discussions}

After centralizing the answers, we found that a significant percentage of the respondents $(64 \%)$ had more than 10 years of experience in this activity sector. Most respondents (53\%) were associates in professional insolvency societies; $18 \%$ were employees/ collaborators in the exercise of the profession, and the remaining performed their activities in insolvency offices.

Most respondents had a significant activity volume, i.e. 40\% handled over 200 insolvency files and 28\% handled between 50 and 200 files. Regarding the number of administered reorganization procedures, $37 \%$ handled over 15 files and $21 \%$ handled between 5 and 15 files.

It is also worth mentioning that according to UNPIR reports, in 2015 there were approx. 35,000 insolvency files; about 5\% were insolvency files (Dutescu \& Stroie, 2018).

The results identified in relation to the risks that generally affect insolvency proceedings are presented below: 


\section{Risks affecting the insolvency proceedings in Romania}

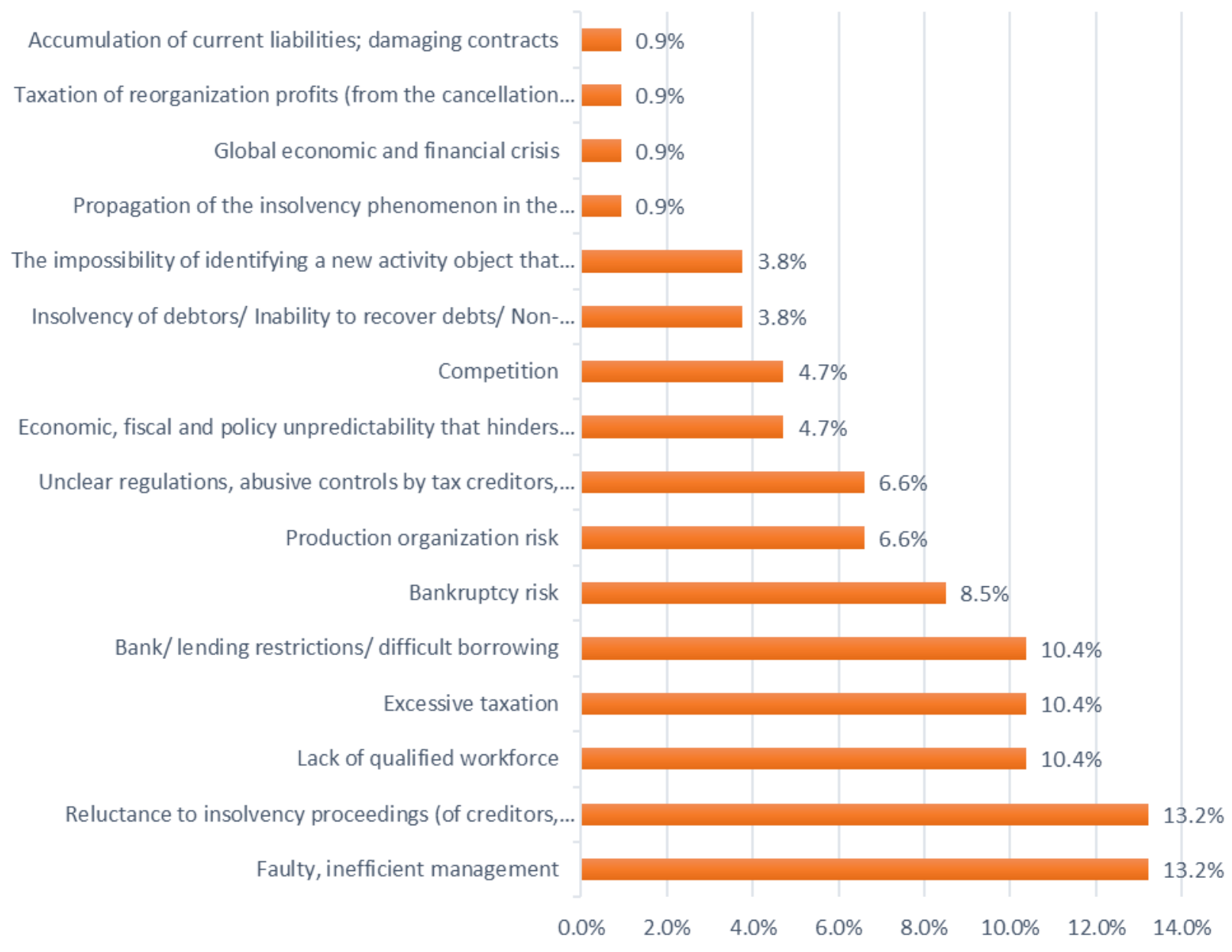

Figure 1. Risks affecting insolvency in Romania

Source: Authors' own research,

In Romania, one of the main risk enhancers in insolvency proceedings is mistrust, i.e. reluctance to insolvency proceedings.

Management quality is another risk that affects companies' insolvency. In most cases, the special administrator is the same person as the statutory administrator; thus, the risk of repeated management mistakes is increased.

Other risks identified in the procedure are represented by the shortage of skilled labor, excessive taxation coupled with fiscal instability, unclear regulations, abusive controls by budget creditors.

Another important aspect of the same risk category, i.e. the fiscal one, is the taxation of reorganization profits in Romania. The reorganization profits are directly related to the 
partial cancellation of debts of insolvency debtors, a legal right that companies have in the reorganization procedure.

Another insolvency risk is the bankruptcy risk, when a company has the chance to reorganize.

Other aspects taken into account by practitioners (as risks in insolvency proceedings) relate to production organization, competition, non-recovery of debtors, political, fiscal and economic unpredictability, the impossibility to draw up and implement a business plan, the actual lack of a business plan, the global economic and financial crisis, the spread of the insolvency phenomenon in the economy triggered by the lack of coercive provisions on opening the insolvency proceedings.

The most important aspect of the study is that insolvency practitioners do not use mathematical/ statistical/ economic models for the company's reorganization decision. Most often, the professionals analyze the financial indicators, but do not pay attention to their correlation and the establishment of levels leading to the idea of liquidation.

Other important issues that practitioners analyze when deciding on the fate of a company are related to:

$\circ$ the debtor's conduct during the observation period,

$\circ$ the existence of the necessary material basis for the continuation of the activity,

- lack of current debts in the procedure,

- a realistic business plan,

- a statement of assets and amounts that would be obtained from capitalization,

$\circ$ knowledge of the business and industry,

$\circ$ a study of the debtor's market,

- analysis of the company's capacity to achieve revenue to cover expenses.

Among the aspects considered important by professionals in the analysis of the reorganization decision, there are the analysis of balance indicators, ongoing contracts, the technical-material base and the availability of appropriate personnel.

Taxation of the reorganization procedure, related to the taxation of profits from reorganization, is an element that professionals take into account when proposing a possible debt cancellation.

Other important issues are the private creditor test, the continuity of the debtor's activity after opening the procedure, the market for products and/ or services, quality management, partners' solvency (customers and suppliers), detailed analysis of the debtor's conduct during the observation period in relation to the accumulated obligations, the conduct regarding the payments made.

The debtor's willingness to reorganize or the existence of a business plan play a less important part in the decision to reorganize a company. Meeting the voting conditions in the creditors' meeting and the social impact of the debtor's insolvency on the market are also issues less considered by professionals.

The risks that affect a successful reorganization procedure are as follows: 
Table 1. Risk successful companies are subjected to

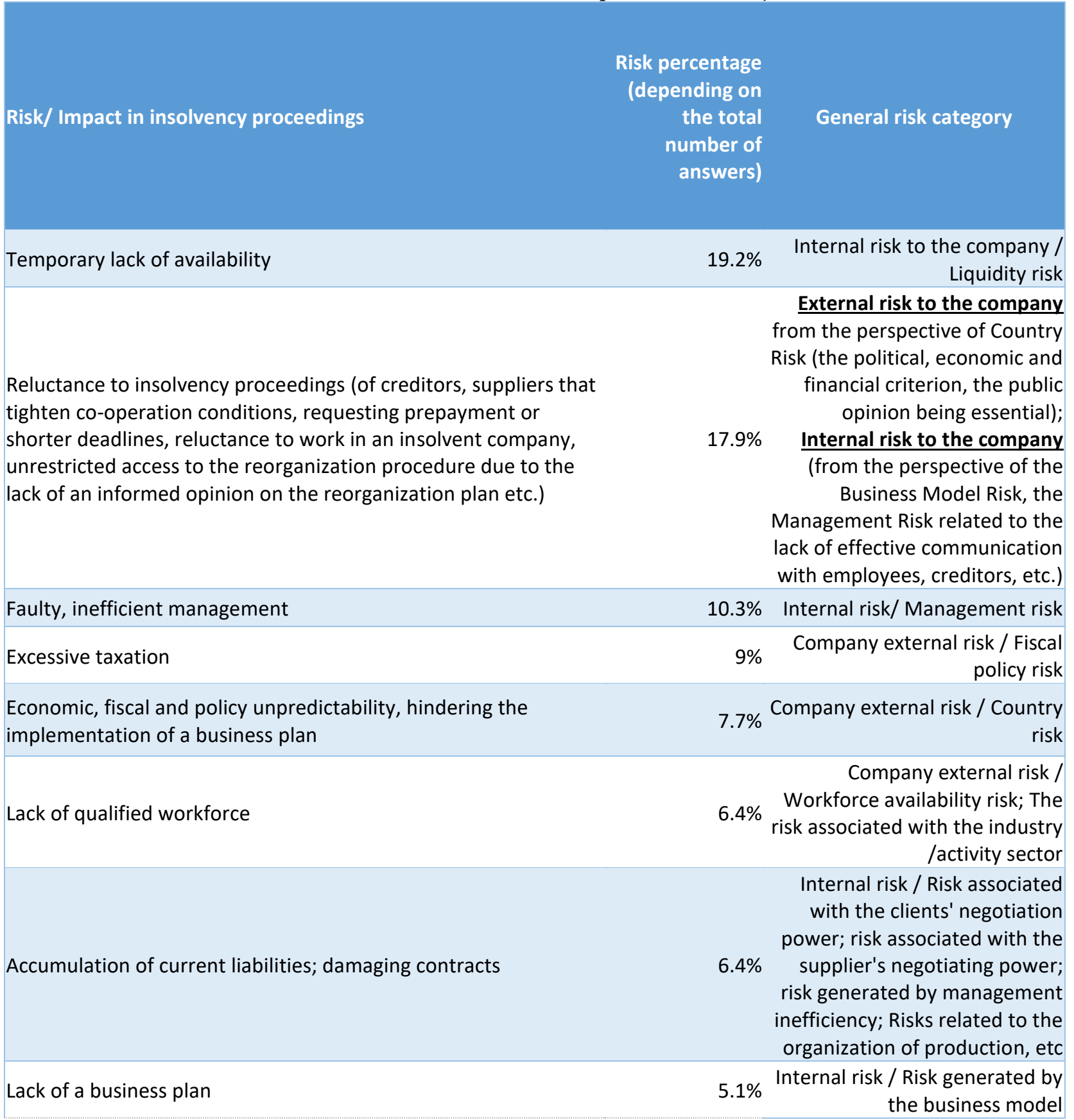

DOI: 10.2478/picbe-2019-0022, pp. 241-253, ISSN 2558-9652| Proceedings of the $13^{\text {th }}$ International Conference on Business Excellence 2019 


\begin{tabular}{|c|c|c|}
\hline $\begin{array}{l}\text { Insolvency of debtors/ Inability to recover debts/ Non-compliance } \\
\text { with payment deadlines }\end{array}$ & $3.8 \%$ & $\begin{array}{r}\text { Internal risk / Risk associated } \\
\text { with the client's negotiating } \\
\text { power; Risk generated by } \\
\text { management inefficiency; Risks } \\
\text { related to the organization of } \\
\text { production, etc }\end{array}$ \\
\hline $\begin{array}{l}\text { Taxation of reorganization profits (from the cancellation of debts, } \\
\text { the discharge of debts under the reorganization plan) }\end{array}$ & $3.8 \%$ & External risk / Fiscal policy risk \\
\hline Bank/ lending restrictions/ difficult borrowing/ high bank charges & $3.8 \%$ & $\begin{array}{r}\text { External risk / Monetary policy } \\
\text { risk }\end{array}$ \\
\hline $\begin{array}{l}\text { Unclear regulations, abusive controls of tax creditors, increased } \\
\text { risk of insolvency }\end{array}$ & $3.8 \%$ & $\begin{array}{l}\text { External risk/ country risk; } \\
\text { Political risk related to unclear } \\
\text { regulations; Legal risk, etc }\end{array}$ \\
\hline $\begin{array}{l}\text { Dependence on a single client / supplier / the impossibility of } \\
\text { negotiating contracts }\end{array}$ & $1.3 \%$ & $\begin{array}{r}\text { Internal risk / Risk generated by } \\
\text { management inefficiency; Risk } \\
\text { associated with the supplier's } \\
\text { negotiating power; Risk } \\
\text { associated with the clients' } \\
\text { negotiating power, etc }\end{array}$ \\
\hline $\begin{array}{l}\text { Lack of specialized institutions for analyzing/ expressing an } \\
\text { opinion on the proposed reorganization plan (legality, } \\
\text { opportunity, reality, etc.) }\end{array}$ & $1.3 \%$ & $\begin{array}{r}\text { External risk/ bankruptcy risk; } \\
\text { Legal risk - operational risk } \\
\text { component }\end{array}$ \\
\hline
\end{tabular}

Source: Authors' own research

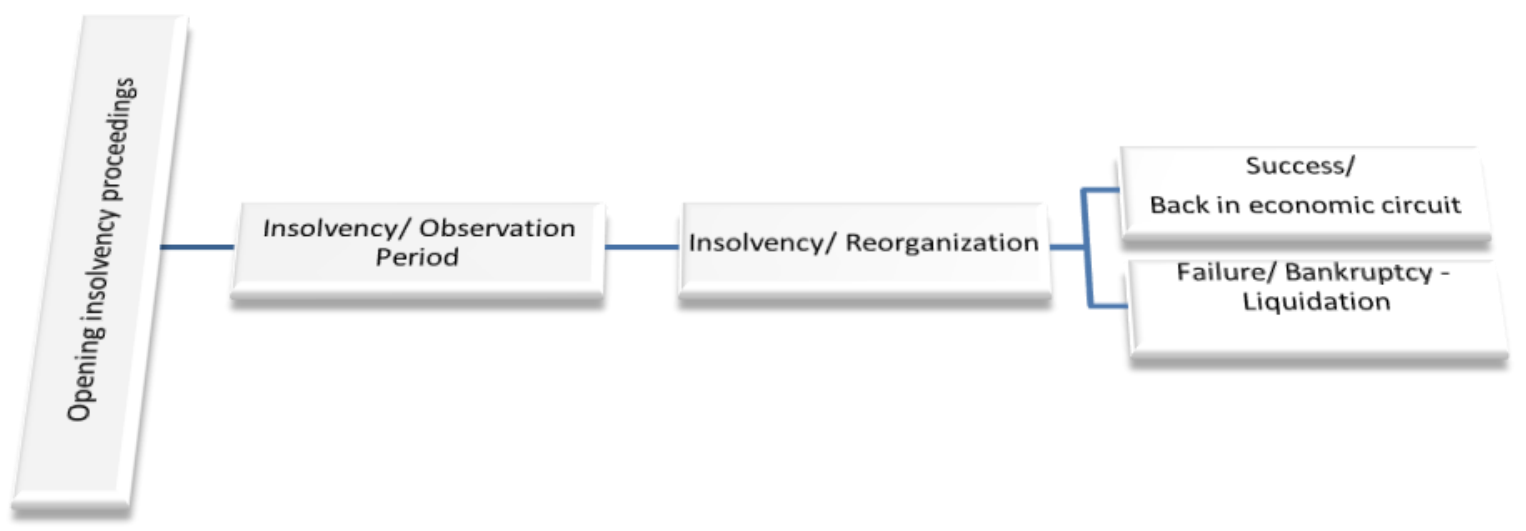

Figure 2. Main stages of the insolvency reorganization process in Romania

Source: Authors' own research

\section{Conclusion}

The completion of a reorganization procedure involves thorough knowledge of the respective procedure, in-depth management knowledge, vision and analytical approach to all the processes and risks involved in the procedure. The specific risk profile of these 
companies combines both internal and external factors. The legislation that encourages the reorganization process cannot exist if the fiscal and monetary policy is not corroborated.

As regards general mistrust in insolvency proceedings, we appreciate that this effect of insolvency propagation in the economy is motivated by many failing reorganization procedures and the lack of a system for the rapid removal from the market of insolvent companies.

PICBE | 251

Certainly, the reorganization procedure can be substantially improved and a model for the reorganization decision analysis would be appropriate in order to eliminate those companies from the economic circuit. On the other hand, it should be taken into account the fact that practitioners do not have the time necessary for in-depth analyzes or for the application of complicated models for bankruptcy prediction. As shown by research results, bankruptcy is only one aspect of the many risks entailed by the reorganization procedure.

Insolvency in Romania is perceived as a stigma, which, unfortunately, very few can overcome (according to UNPIR reports, in 2015, only 5\% of the insolvency files underwent the reorganization procedure; the success of the plan did not exceed $1-3 \%$ of the reorganization procedures).

\section{References}

Altman, EI. (1968). Financial Ratios, Discriminant Analysis and the Prediction of Corporate Bankruptcy. The Journal of Finance, 23: 589-609.

Black, F. \& Scholes, M. (1973). The pricing of options and corporate liabilities. J. Polit. Econ., 81: 637-659. DOI: 10.1086/260062.

Cameron, K. et al., (1983). Organizational Life Cycles and Shifting Criteria of Effectiveness: Some Preliminary Evidence. Management Science 29(1):33-51.

Chandler, A.D. (1962). Strategy and Structure: Chapters in the History of American Enterprise. MIT Press, Boston.

Coldwell C. et al., (2004). Book Review Essay: Effective Governance in Managing Change: Common Perspective from Two Lenses. The Academy of Management Review 29(2):296.

Daltu, T. (2006). Abordari in economia riscului si incertitudinii" Editura Economica.

Dutescu, A. \& Stroie, C. (2018). The enterprise risk profile - a financial and managerial health indicator - comparative study. Proceedings of the International Conference on Business Excellence, Volume 12, Issue 1, Pages: 349-362. 10.2478/picbe-2018-0031.

Éva Pálinkó \& Tamás Tóth, (2017). Efficient Bankruptcy and Reorganisation in Domestic Practice. Public Finance Quarterly, State Audit Office of Hungary, vol. 62(3), pages 326-347.

Ghazzawi, I. and Cook, T. (2015). Organizational Challenges and Failures: A theoretical Framework and a Proposed Model. Journal of Strategic and International Studies. Vol. $\mathrm{X}(2), 40-62$.

Ghazzawi, Issam. (2018). Organizational Turnaround: A Conceptual Framework and Research Agenda. 17.

Giné. X. \& Love, I. (2006). Do Reorganization Costs Matter for Efficiency? Evidence from a Bankruptcy Reform in Colombia. Journal of Law and Economics, University of Chicago Press, vol. 53(4), pages 833-864. 
Glaser, B. G., \& Strauss, A. L. (1967). The discovery of grounded theory: Strategies for qualitative research. Hawthorne, NY: Aldine.

Goulding, C. (2002). Grounded theory: A practical guide for management, business and market researchers. Thousand Oaks CA.: Sage Publications.

Haynes, J. (1895). Risk as an Economic Factor. The Quarterly Journal of Economics, Volume 9, Issue 4, Pages 409-449, https://doi.org/10.2307/1886012.

J.B. Clark, (1899). The Distribution of Wealth: A Theory of Wages, Interest and Profits.

Laitinen, E.K. (2010) Financial and Non-Financial Variables in Predicting Failure of Small Business Reorganization: Comparison of Logistic Regression Analysis and Survival Analysis. International Journal of Accounting and Finance, 4, 1-34. https://doi.org/10.1504/IJAF.2013.053111.

Laitinen, E.K., (2008). Data sistem for assesing probability of failure in SME reorganization. Industrial Management \& Data Sistem, Vol. 108, No. 7, pp. 849-866.

Linda Gabbianelli, (2018). A territorial perspective of SME's default prediction models, Studies in Economics and Finance, Vol. 35 Issue: 4, pp.542-563, https://doi.org/10.1108/SEF-08-2016-0207.

Liou, D.K.\& Smith, M., (2007). Financial distress and corporate turnaround: a review of the literature and agenda for research, Accounting, Accountability and Performance, Vol. 13, No. 1, pp.74-114.

Lohrke, F. T., Bedeian, A. G., \& Palmer, T. B. (2004). The role of top managementteams in formulating and implementing turnaround strategies: A review andresearch agenda. International Journal of Management Reviews, 5-6(2): 63-90.

Markowitz, H. (1952) Portfolio Selection. The Journal of Finance, 7, 77-91. https://doi.org/10.1111/j.1540-6261.1952.tb01525.x

Neli, Muntean. (2018). Analiza şi evaluarea riscurilor la nivel de întreprindere: aspecte teoretice şi applicative. Departamentul editorial- poligrafic al ASEM.

Neumann, J., Morgenstern, O., 1944. Theory of Games and Economic Behavior. Princeton University Press, pp.625.

Oliver Lukason, Erkki K. Laitinen, Arto Suvas, (2016). Failure processes of young manufacturing micro firms in Europe, Management Decision, Vol. 54 Issue: 8, pp.1966-1985, https://doi.org/10.1108/MD-07-2015-0294.

Oliver Lukason, Tiia Vissak, (2017) Failure processes of exporting firms: evidence from France, Review of International Business and Strategy, Vol. 27 Issue: 3, pp.322-334, https://doi.org/10.1108/RIBS-03-2017-0020.

Pugna, Irina \& Adriana, Dutescu \& Stanila, Georgiana. (2018). Performance management in the data-driven oragnisation. Proceedings of the International Conference on Business Excellence. 12. 816-828. 10.2478/picbe-2018-0073.

Ramkrishnan (Ram) V. Tenkasi, Yehia Kamel, (2016). To Bankruptcy and Back: Turnaround Strategies for Firm Emergence, Long-Term Survival, and Speed. Debra A. Noumair, Abraham B. (Rami) Shani (ed.) Research in Organizational Change and Development (Research in Organizational Change and Development, Volume 24) Emerald Group Publishing Limited, pp.221 - 259. 
Routledge, J. \& Gadenne, D. (2004), An exporatory study of the company reorganisationreorganization decision in voluntary administration, Pacific Accounting Review, Vol. 16, pp. 31-56.

Smith, M.\& Graves, C., (2005). Corporate turnaround and financial distress, Managerial Auditing Jurnal, Vol. 20, No.3, pp. 304-20

Stroie, C. \& Mirea, M. (2016). Concrete Aspects Regarding the Imputation of Current Tax

PICBE | 253 Receivables în Insolvency Proceedings. Ovidius University Annals, Economic Sciences Series, vol. XVI, issue 2, pp.554

Trahms, Cheryl \& Achidi Ndofor, Hermann \& Sirmon, David. (2013). Organizational Decline and Turnaround A Review and Agenda for Future Research. Journal of Management. 39. 1277-1307. 10.1177/0149206312471390.

Whitman, Michael E. and Amy B. Woszczynski, eds. The Handbook of Information Systems Research. Hershey PA: IGI Global, 2003.

Willett, A. H., (1901) The Economic Theory of Risk and Insurance.

Wood, Oliver G. (1964). Evolution of the Concept of Risk. The Journal of Risk and Insurance, vol. 31, no. 1, pp. 83-91. JSTOR, www.jstor.org/stable/251211. 